Ciencias Marinas (2001), 27(4): 481-500

http://dx.doi.org/10.7773/cm.v27i4.504

\title{
RELATIONSHIPS BETWEEN ENVIRONMENTAL VARIABLES AND THE ABUNDANCE OF PERACARID FAUNA IN ALGECIRAS BAY (SOUTHERN IBERIAN PENINSULA)
}

\section{RELACIONES ENTRE LAS VARIABLES MEDIOAMBIENTALES Y LA ABUNDANCIA DE LA FAUNA DE PERACÁRIDOS EN LA BAHÍA DE ALGECIRAS (SUR DE LA PENÍNSULA IBÉRICA)}

\author{
Mercedes Conradi* \\ Pablo J. López-González \\ Laboratorio de Biología Marina \\ Departamento de Fisiología y Biología Animal \\ Facultad de Biología \\ Universidad de Sevilla \\ Apartado 1095, E-41080 Sevilla, Spain. \\ * E-mail: Mconradi@cica.es \\ Recibido en febrero de 2001; aceptado en julio de 2001
}

\begin{abstract}
The distribution and abundance of peracaridean fauna associated with the bryozoan Bugula neritina have been analysed according to their possible relationships with environmental stress on the coastline of Algeciras Bay. The spatial environmental variability along this bay has been established based on the analysis of five abiotic variables (hydrodynamism, siltation, suspended solids, and organic matter content) at six stations over a 12-month period. The temporal variability of these abiotic variables was not taken into account due to the method used in collecting the samples. The abundance and beta diversity of the peracarid fauna were also calculated monthly. Hydrodynamism was the only abiotic variable significantly correlated with beta diversity, with a linear regression model between the two variables $(r=0.81)$. The distributional pattern of the peracarids (based on the abundance matrix) was correlated with the environmental variables by matching samples' similarities using the Spearman rank correlation. This analysis showed that the combination of variables that best explains the patterns of distribution is hydrodynamism and siltation $\left.\rho_{s}=0.665\right)$. Of the species considered the amphipods Ischyrocerus inexpectatus, Jassa marmorata and Podocerus variegatus were negatively correlated with hydrodynamism and positively with temperature. The caprellidea Phtisica marina was also negatively correlated with hydrodynamism. On the other hand, the amphipods Cressa mediterranea and Stenothoe dollfusi preferred environments with high hydrological forces and low sedimentation rate. Due to the particular environmental conditions where they live and their requirements, Gammaropsis maculata, Corophium acutum, J. marmorata, I. inexpectatus, and P. variegatus were categorised as good indicator species in port environments. Others such as Aora spinicornis, Microjassa cumbrensis, and C. mediterranea were categorised as species well adapted to high hydrological forces.
\end{abstract}

Key words: Peracarids, environmental stress, Algeciras Bay, Bugula neritina. 
Ciencias Marinas, Vol. 27, No. 4, 2001

\section{RESUMEN}

Se han estudiado las relaciones entre la distribución y abundancia de la fauna de peracáridos asociados al briozoo Bugula neritina con el estrés medioambiental producido en la costa de la Bahía de Algeciras. La variabilidad espacial del estrés medioambiental a lo largo de la Bahía de Algeciras se ha establecido en base a cinco variables abióticas (hidrodinamismo, sedimentación, materia orgánica disuelta en el agua, sólidos en suspensión y la materia orgánica de dichos sólidos en suspensión) a lo largo de seis estaciones de muestreo durante 12 meses de estudio. La temporalidad de las variables medioambientales no se ha estudiado debido al método de muestreo utilizado para éstas. Sin embargo, se calcularon mensualmente tanto la abundancia como la diversidad beta de la fauna de peracáridos en cada una de las estaciones. El hidrodinamismo fue la única variable abiótica correlacionada significativamente con la diversidad beta, existiendo una relación lineal entre ambas variables $(r=0.81)$. El patrón de distribución de los peracáridos (basado en la matriz de abundancia) se relacionó con las variables abióticas usando el coeficiente de correlación de Spearman. Este análisis determinó que las variables que mejor explican los patrones de distribución de los peracáridos son el hidrodinamismo y la sedimentación $\left(\rho_{s}=0.665\right)$. Entre las especies consideradas, los anfípodos Ischyrocerus inexpectatus, Jassa marmorata y Podocerus variegatus se correlacionaron negativamente con el hidrodinamismo y positivamente con la temperatura. El caprélido Phtisica marina también estuvo relacionado negativamente con el hidrodinamismo. Por el contrario, los anfípodos Cressa mediterranea y Stenothoe dollfusi prefirieron hábitats con un fuerte hidrodinamismo y baja sedimentación. Debido a las condiciones ambientales particulares en las que estas especies viven y en base a sus necesidades alimentarias, Gammaropsis maculata, Corophium acutum, J. marmorata, I. inexpectatus, y $P$. variegatus han sido catalogadas como especies indicadoras de ambientes portuarios. Otras como Aora spinicornis, Microjassa cumbrensis y $C$. mediterranea se han considerado especies bien adaptadas a hábitats con fuerte hidrodinamismo.

Key words: Peracáridos, estrés medioambiental, Bahía de Algeciras, Bugula neritina.

\section{INTRODUCTION}

Benthic communities, due to their relatively long-term ecological memory, allow us to evaluate the effects of environmental factors (Pearson and Rosenberg, 1978; Carrada and Fresi, 1988). In fact, the analysis of changes in the structure of benthic communities has become one of the mainstays for detecting and monitoring the biological effects of marine pollution (Warwick and Clarke, 1993). Algeciras Bay has suffered large human interventions which have made this an interesting ecological system to biomonitor.

Earlier studies (Conradi et al., 1997; 2000) on the spatio-temporal distribution of the peracaridean faunas associated with the bryozoan

\section{INTRODUCCIÓN}

Las comunidades bentónicas, debido a su relativa memoria ecológica de largo plazo, nos permiten evaluar los efectos de las variables medioambientales (Pearson y Rosenberg, 1978; Carrada y Fresi, 1988). De hecho, el estudio de los cambios estructurales de estas comunidades ha empezado a considerarse como uno de los principales pasos para detectar y establecer el efecto biológico de la polución marina (Warwick y Clarke, 1993). La Bahía de Algeciras ha sufrido un gran número de modificaciones debidas a la intervención humana que le ha convertido en un interesante sistema ecológico para su estudio desde el punto de vista medioambiental. 
Conradi et al.: Environmental variables and peracarid fauna in Algeciras Bay

Bugula neritina L., in Algeciras Bay suggested three basic distributional patterns: (a) a large number of non-abundant species, which did not attain $2 \%$ of the total abundance, exclusively distributed at the extremes of the bay, (b) species occurring throughout the bay, but more abundant in the centre of the bay and (c) species occurring throughout the bay but more abundant in the extremes of the bay. It was also pointed out that the greater total abundance of some peracaridean species at certain stations in Algeciras Bay, may indicate an environmental preference (Conradi et al., 2000). The objective of the present study is to examine the relationship between the spatial distribution of the peracarids and physicochemical factors.

\section{MATERIAL AND METHODS}

Six stations were located along the coastline from the internal to the external areas of Algeciras Bay (fig. 1). A description of the area of study as well as the sampling method of the peracarids is detailed in Conradi et al. (2000). Briefly, four replicate samples were taken at six stations throughout one year. Each sample consisted of a single colony of the briozoan Bugula neritina, pocketed in situ and extracted from the bottom by SCUBA diving. Peracaridean densities were expressed as a function of the colonies' dry mass. The influence of both volume and biomass of the substratum on the peracaridean community has been already studied (Conradi et al., 2000).

The beta diversity at each station was calculated according to Wilson and Shmida (1984):

$$
\beta_{w}=\frac{S}{\alpha-1}
$$

where $S$ is the total number of species recorded in the sampling station, and $\alpha$ is the average number of species found within the community samples.
Estudios anteriores (Conradi et al., 1997, 2000) sobre la distribución espacio-temporal de los peracáridos asociados al briozoo Bugula neritina L. en la Bahía de Algeciras establecieron tres patrones básicos de distribución: (a) especies poco abundantes, que no alcanzaron el $2 \%$ de la abundancia total y que se encuentran distribuidas únicamente en las estaciones extremas de la bahía; (b) especies distribuidas a lo largo de toda la bahía pero cuya abundancia es mayor en las estaciones internas; y (c) especies que se distribuyen a lo largo de toda la bahía pero son más abundantes en las estaciones extremas. También se indicó que las diferencias entre la abundancia de determinadas especies de peracáridos a lo largo de la bahía podría indicar una posible preferencia medioambiental (Conradi et al., 2000). El objetivo del presente estudio es examinar las relaciones entre la distribución espacial de los peracáridos y las variables fisico-químicas de la Bahía de Algeciras.

\section{MATERIAL Y MÉTODOS}

Se han estudiado seis estaciones estableciendo un gradiente desde las áreas internas hasta la zona externa de la Bahía de Algeciras (fig. 1). En Conradi et al. (2000) hay una descripción detallada tanto del área de estudio como de la metodología empleada para la captura de los peracáridos. Resumiendo, se recolectaron cuatro réplicas de las muestras en cada una de las seis estaciones muestreadas a lo largo de un año. Cada muestra consistía en una colonia del briozoo Bugula neritina, la cual había sido embolsada bajo el agua mediante buceo autónomo. La densidad de los peracáridos se expresó como una función del peso seco de las colonias. La influencia tanto del volúmen como de la biomasa del sustrato sobre esta comunidad ya ha sido estudiada previamente (Conradi et al., 2000). 
The environmental variability among stations was established based on five abiotic variables that could be related with environmental stress including hydrodynamism, siltation, suspended solids, suspended organic matter and organic matter in the silt gathered in collecting bottles (SOM). Measurements were made as in Gambi et al. (1989) for hydrodynamism, Moore (1972) for siltation and Strickland and Parson (1969) for the other three factors. Temperature and salinity were also recorded monthly at each station.

As a previous step to the statistical analysis application, the variables were transformed to normality: log-transformation was used for environmental factors and fourth-root transformation was used for the species' abundance.

Faunal similarities among the sampling stations were examined by means of a classification analysis. Total mean abundance of each species present in the 12-month period at the studied stations were used for this analysis since the seasonal variation of substratum and of the peracarid fauna were already studied (Conradi et al., 2000). This similarity matrix for the classification was calculated by means of the Bray-Curtis index, since this index is not influenced by joint absences (Bray-Curtis, 1957). The results were then graphically described by using dendrograms with the UPGMA ("unweighted pair-group method using centroids") aggregation algorithm (Sneath and Sokal, 1973), and by mapping the stations inter-relationships in an ordination by non-metric multidimensional scaling (MDS) (Clarke and Warwick, 1994). The species mainly responsible for the dissimilarity among sampling stations were determined according to Clarke (1993), using the SIMPER computer program.

In order to link the multivariate community structure (reflected in the faunistic heterogeneity of the different sampling stations) to environmental variables (which also changed at
La diversidad beta fue calculada, para cada una de las estaciones, según Wilson y Shmida (1984):

$$
\beta_{w}=\frac{S}{\alpha-1},
$$

donde $S$ es el número total de especies encontradas en la estación muestreada y $\alpha$ es el promedio del número de especies encontradas en las muestras.

La variabilidad medioambiental en las distintas estaciones fue establecida en base a cinco variables abióticas que pueden estar relacionadas con el estrés medioambiental. Entre ellas se encuentran el hidrodinamismo, la sedimentación, los sólidos en suspensión, la materia orgánica de los sólidos en suspensión y la del sedimento recolectado en las trampas de sedimentación (SOM). El hidrodinamismo se midió de acuerdo a Gambi et al. (1989); para la sedimentación se siguió la metodología de Moore (1972); y las variables restantes se midieron de acuerdo a Strickland y Parson (1969). La temperatura y la salinidad también se tomaron mensualmente en cada estación.

Como paso previo a los análisis estadísticos, las variables fueron normalizadas mediante las siguientes transformaciones: para las variables medioambientales se utilizó el logaritmo en base diez y la raiz cuarta para los datos de abundancia.

Las similitudes de la fauna entre estaciones se estableció mediante un análisis de clasificación. Se utilizó el promedio de la abundancia de las especies encontradas en los 12 meses estudiados ya que la variabilidad temporal tanto del sustrato como de los peracáridos fue previamente estudiada (Conradi et al., 2000). La matriz de similitud, basada en la fauna de peracáridos, fue calculada utilizando el índice de Bray-Curtis, el cual no se encuentra influenciado por las dobles ausencias (Bray-Curtis, 1957). El resultado fue ilustrado gráficamente con un dendrograma con el algoritmo de 


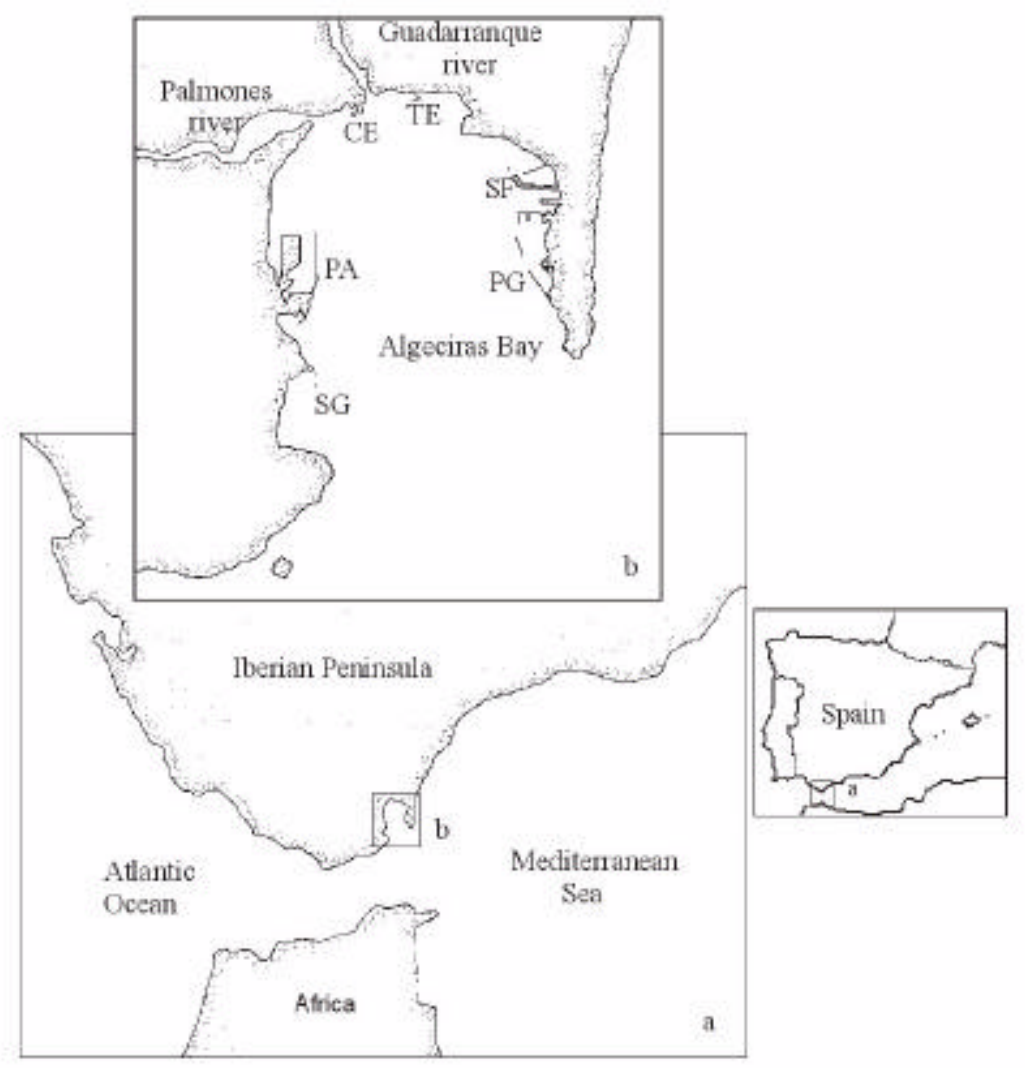

Figure 1. Research area showing benthic stations. SG, San García; PA, Algeciras harbour; TE, Sevillana Thermal Power Station; CE, CEPSA Petrochemical Complex Station; SF, San Felipe harbour; PG, Gibraltar harbour.

Figura 1. Área de estudio mostrando las estaciones bénticas. SG, San García; PA, Puerto de Algeciras; TE, Sevillana de Electricidad; CE, Complejo Petroquímico de CEPSA; SF, Puerto de San Felipe; PG, Puerto de Gibraltar.

each station), we used two different but complementary statistical techniques:

(1) The BIO-ENV procedure (Clarke and Ainsworth, 1993) which consists of the separate comparison of stations ordinations from biotic and abiotic variables, and choosing that subset of environmental variables that provides the best match between the two configurations. Agreement between agregación UPGMA (Sneath and Sokal, 1973), que muestra las relaciones entre las estaciones en una ordenación no métrica y multidimensional (MDS) (Clarke y Warwick, 1994). Las especies responsables de la disimilitud entre las estaciones de muestreo se determinaron según Clarke (1993) utilizando el programa SIMPER.

Se utilizaron dos técnicas estadísticas complementarias para establecer las relaciones 
Ciencias Marinas, Vol. 27, No. 4, 2001

ordination patterns is determined by the Spearman rank correlation coefficient; and

(2) Multiple regression models were used to determinate the influence of the independent environmental variables on the abundance of some characteristic species of the groups of stations identified by the Cluster and MDS analyses.

The software used was PRIMER from Plymouth Marine Laboratory for MDS, SIMPER and BIO-ENV analyses; and STATGRAPHICS for multiple "box-and-whister" plots, regressions and multiple regression models.

\section{RESULTS}

\section{Stations grouping from species composition}

A total of 67 peracaridean species (52 amphipods, 5 tanaidacean, 8 isopods and 2 cumaceans) were found to be associated with Bugula neritina in Algeciras Bay. The total number of species varied considerably among stations and with time. Generally, the main differences occurred between the group of stations situated at the innermost parts of the bay (TE, $\mathrm{CE}$ and SF) and the group of stations most externally situated (SG, PA and PG). The highest species richness (37 species) occurred at SG and PG in June and February, respectively, and the lowest one at TE and CE (12 species) in April (see Conradi et al., 2000 for more details about the spatio-temporal distribution). Similarly, beta diversity $\left(\beta_{\mathrm{w}}\right)$ values were highest at stations located near the mouth of the bay with maximum values of 1.71 (SG), $1.6(\mathrm{PA})$ and 1.54 (PG). The maximum values obtained by the inner stations were $1.2(\mathrm{CE})$ and 1.1 (TE and SF).

Cluster analysis based on the total mean abundance of species distinguished two main groups of sites (fig. 2a). The first group (G1) entre la estructura de la comunidad (reflejada en la heterogeneidad de las diferentes estaciones de muestreo) y las variables medioambientales (que también variaron en cada estación):

(1) El test BIO-ENV (Clarke y Ainsworth, 1993), que consiste en la comparación de las ordenaciones obtenidas de las estaciones según las variables bióticas y abióticas, y en la elección del conjunto de variables medioambientales que mejor combinan las dos configuraciones. La posible correspondencia entre estas dos configuraciones se determinó gracias al coeficiente de Spearman; y

(2) Se utilizaron los modelos de regresión múltiple para determinar la influencia de las variables medioambientales independientes en la abundancia de aquellas especies de peracáridos características de los grupos de estaciones detectados por los análisis de agrupamiento y MDS.

El paquete estadístico utilizado fue el PRIMER del Plymouth Marine Laboratory para los análisis MDS, SIMPER y BIO-ENV; y el STATGRAPHICS para las gráficas "box-andwhister", y las regresiones simples o múltiples.

\section{RESULTADOS}

\section{Agrupación de las estaciones de acuerdo a la composición de las especies}

Se han encontrado un total de 67 especies de peracáridos (52 anfípodos, 5 tanaidáceos, 8 isópodos y 2 cumáceos) asociados a $B$. neritina en la Bahía de Algeciras. El número total de especies varió considerablemente entre las distintas estaciones y con el tiempo. Generalmente las diferencias más grandes se produjeron entre el grupo de las estaciones internas (TE, CE y SF) y aquellas situadas en las partes más externa de la bahía (SG, PA y PG). La riqueza específica más alta (37 especies) se encontró en 
A

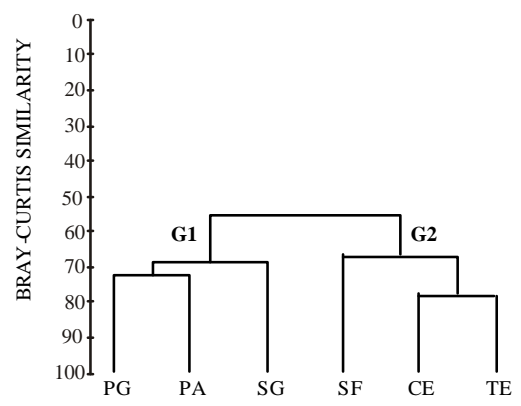

B

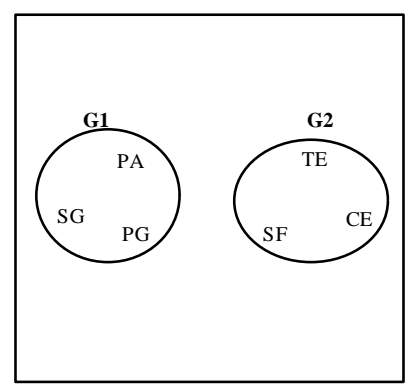

Figure 2. Cluster (A) and MDS ordination (B) analyses of stations using group-average clustering from Bray-Curtis similarity on species abundances (stress $=0.009$ ) Stations code as in figure 1 .

Figura 2. Análisis de ordenamiento (A) y de ordenación MDS (B) de las estaciones utilizando el índice de similaridad de Bray-Curtis, basado en las abundancias de las especies (estrés $=0.009$ ). Código de las estaciones como en la figura 1.

included the outer harbour stations (PA, PG), which were closer to each other than they were to the outermost station (SG). The second group (G2) included the inner stations. Within the $\mathrm{G} 2$ group, CE and TE had the strongest faunal similarity (79\%) as they were geographically closer and had a large number of common species. Moreover, there was approximately $68 \%$ of similarity between these two stations and SF which is the inner station closer to the outer stations. The results of the MDS analysis (fig. 2b) supported those obtained by the Cluster analysis.

In terms of abundance, thirty-five species were responsible for more than $70 \%$ of the dissimilarity between G1 and G2, defined by the
SG y PG en el mes de junio y febrero, respectivamente, y la más baja en TE y CE (12 especies) en Abril (ver Conradi et al., 2000, para más detalles sobre la variación espaciotemporal de la distribución). De forma similar, la diversidad beta $\left(\beta_{w}\right)$ fue alta en aquellas estaciones situadas cerca de la entrada de la bahía con valores máximos de 1.71 (SG), $1.6(\mathrm{PA})$ y 1.54 (PG); los valores máximos obtenidos fueron de 1.2 (CE) y 1.1 (TE y SF).

El dendrograma basado en el promedio total de abundancias de las especies distinguió dos grupos de estaciones (fig. 2a). El primer grupo (G1) incluyó las estaciones externas (PA, PG), las cuales se encontraron más cerca entre ellas que de la estación más externa (SG). 
Ciencias Marinas, Vol. 27, No. 4, 2001

Cluster and MDS analyses (table 1). As the stations included in G1 had higher species richness and beta diversity values, it was not surprising that the principal contributions to dissimilarity (high values of the $\delta_{i} / \operatorname{SD}\left(\delta_{i}\right)$, Clarke, 1993) came from species that were frequent in G1 group and largely or totally absent in G2. These species were the cumacean Nannnastacus unguiculatus, and the amphipods Stenothoe dollfusi, Microprotopus sp. Eusiroides dellavallei and Ampithoe ramondi. On the other hand, from the species that are likely to be good discriminators in these groups, only three amphipod species, Jassa marmorata, Podocerus variegatus and Stenothoe tergestina, were more frequent in G2 than in G1 (table 1).

\section{Environmental variables}

The values obtained for the environmental factors were not taken as representative of the variation within each month as their measurement can not certainly reflect the monthly behaviour, because of the sampling devices available and the methods used. Therefore, this study only considered the spatial patterns of the environmental factors (fig. 3).

Hydrodynamism was clearly inversely related to spatial location, as shown by the differences between the group of stations located at the inner area of the bay and the outer group of stations. The highest mean annual hydrodynamic value was registered at SG $(6.14 \mathrm{~V})$, which also had the maximum annual value (11.15 V).

Siltation tended to be higher at the eastern portion of the bay, although the maximum annual siltation values recorded at stations SG and PA (10.2 and $10.38 \mathrm{~g} \mathrm{~m}^{-2} \mathrm{mo}^{-1}$, respectively) were lower than the value obtained at the station CE $\left(18.4 \mathrm{~g} \mathrm{~m}^{-2} \mathrm{mo}^{-1}\right)$. The station TE had the maximum annual values
El segundo grupo (G2) abarcó a las estaciones más internas de la bahía. Dentro del grupo G2, CE y TE mostraron la mayor similitud faunística $(79 \%)$ ya que fueron las estaciones más cercanas desde el punto de vista geográfico y presentaron también un gran número de especies comunes. Además, entre estas dos estaciones hubo aproximadamente un $68 \%$ de similitud con SF, la estación interna más cercana a las estaciones externas. Los resultados de la MDS (fig. 2b) fueron similares a los obtenidos en el dendrograma.

En términos de abundancia, treinta y cinco especies fueron responsables de más del $70 \%$ de la disimilitud entre los grupos G1 y G2, definidos por el dendrograma y la MDS (tabla 1). No es sorprendente que las especies que contribuyen más a la disimilitud entre estos dos grupos (valores altos de $\delta_{i} / \operatorname{SD}\left(\delta_{i}\right)$, Clarke, 1993) sean frecuentes en G1 y muy raras o inexistentes en G2, ya que G1 incluye estaciones con mayor diversidad y riqueza específica. Estas especies son: el cumáceo Nannastacus unguiculatus, y los anfípodos Stenothoe dollfusi, Microprotopus sp., Eusiroides dellavallei y Ampithoe ramondi. Por el contrario, sólo tres de las especies de anfípodos discriminaron claramente los dos grupos (Jassa marmorata, Podocerus variegatus y Stenothoe tergestina), ya que fueron más abundantes en G2 que en G1 (tabla 1).

\section{Variables medioambientales}

Las cinco variables ambientales estudiadas no se consideraron representativas de la variación mensual puesto que no se pudo saber con exactitud cuán representativas fueron las muestras tomadas dada la metodología empleada. Por tanto, este estudio sólo analiza los patrones espaciales de estas variables (fig. 3) puesto que sólo se obtuvo una medida de dichas variables 
Conradi et al.: Environmental variables and peracarid fauna in Algeciras Bay

Table 1. Average abundance $(\bar{Y})$ of important peracaridean species in groups G1 (outer stations) and G2 (inner stations) at Algeciras Bay. Species are listed according to their contribution $\left(\delta_{i}\right)$ to average dissimilarity $\delta_{i}=43.54(\mathrm{SD}=3.6)$ between the two groups.

Tabla 1. Abundancia media $(\bar{Y})$ de especies importantes de peracáridos en los grupos de estaciones G1 (externas) y G2 (internas) de la Bahía de Algeciras. Las especies se enlistan de acuerdo a su contribución ( $\delta$ ) al promedio de disimiltud $\delta=43.54(\mathrm{DS}=3.6$ ) entre ambos grupos.

\begin{tabular}{|c|c|c|c|c|}
\hline Species & $\bar{Y}_{\mathrm{G} 2}$ & $\bar{Y}_{\mathrm{G} 1}$ & $\bar{\delta}_{\mathrm{i}} / \mathrm{SD}\left(\delta_{i}\right)$ & $\Sigma_{\delta_{i}} \%$ \\
\hline Jassa marmorata Holmes, $1903 *$ & 21462.63 & 364.13 & 3.45 & 5.29 \\
\hline Stenothoe tergestina (Nebeski, 1880)* & 2500.11 & 7.14 & 3.14 & 9.74 \\
\hline Microjassa cumbrensis Stebbing y Robertson, 1891 & 157.89 & 1156.04 & 1.72 & 12.90 \\
\hline Stenothoe dollfusi Chevreux, $1887 *$ & 130.58 & 3435.48 & 4.97 & 15.93 \\
\hline Podocerus variegatus Leach, $1814 *$ & 9130.74 & 467.61 & 2.96 & 18.89 \\
\hline Nannastacus unguiculatus (Bate, 1859)* & 0.77 & 431.50 & 6.81 & 21.83 \\
\hline Microprotopus sp.* & 1.28 & 407.09 & 4.30 & 24.69 \\
\hline Caprella equilibra Say, 1818 & 3321.77 & 50.32 & 1.05 & 27.45 \\
\hline Paranthura nigropunctata Norman y Stebbing, 1886 & 22.08 & 1151.05 & 1.71 & 29.89 \\
\hline Caprella acanthifera Leach, 1814 & 3399.63 & 149.00 & 1.72 & 32.30 \\
\hline Aora spinicornis (Bate, 1857) & 1.00 & 974.63 & 1.47 & 34.70 \\
\hline Pseudoprotella phasma (Montagu, 1804) & 8806.16 & 2238.39 & 1.13 & 36.96 \\
\hline Stenothoe eduardi Krapp-Schieckel, 1976 & 241.16 & 1837.77 & 2.12 & 39.14 \\
\hline Cressa mediterranea Ruffo, 1979 & 156.37 & 341.47 & 1.70 & 41.30 \\
\hline Corophium acutum Chevreux, 1908 & 378.37 & 4.37 & 2.35 & 43.34 \\
\hline Phtisica marina Slabber, 1769 & 8015.47 & 2768.92 & 1.40 & 45.33 \\
\hline Tanais dulongii (Audouin, 1826) & 9.29 & 232.38 & 1.53 & 47.20 \\
\hline Tritaeta gibbosa (Bate, 1862) & 0.00 & 164.65 & 1.86 & 49.05 \\
\hline Lembos websteri Bate, 1857 & 313.76 & 2.65 & 1.49 & 50.87 \\
\hline Corophium sextonae Crawford, 1937 & 0.00 & 126.28 & 1.26 & 52.68 \\
\hline Ischyrocerus inexpectatus Ruffo, 1959 & 435.79 & 183.45 & 1.34 & 54.28 \\
\hline Apherusa bispinosa (Bate, 1857) & 2.91 & 98.44 & 1.39 & 55.87 \\
\hline Stenothoe monoculoides (Montagu, 1813) & 0.00 & 189.90 & 0.92 & 57.46 \\
\hline Dexamine spiniventris (A. Costa, 1853) & 38.45 & 536.33 & 1.30 & 59.04 \\
\hline
\end{tabular}


Ciencias Marinas, Vol. 27, No. 4, 2001

Table 1 (Cont.)

\begin{tabular}{lrrrr}
\hline Species & $\bar{Y}_{\mathrm{G} 2}$ & $\bar{Y}_{\mathrm{G} 1}$ & $\delta_{\mathrm{i}} / \mathrm{SD}\left(\delta_{i}\right)$ & $\Sigma_{\delta_{i}} \%$ \\
\hline Eusiroides dellavallei Chevreux, 1899* & 0.00 & 33.67 & 3.82 & 60.62 \\
Amphilochus picadurus J.L Barnard, 1962 & 412.08 & 1435.37 & 1.54 & 62.17 \\
Caprella penantis Leach, 1814 & 28.77 & 230.27 & 1.49 & 63.70 \\
Iphimedia minuta G.O Sars, 1882* & 0.00 & 29.91 & 3.03 & 65.12 \\
Lysianassa costae Milne Edwards, 1830 & 13.47 & 108.10 & 1.62 & 66.50 \\
Ericthonius brasiliensis (Dana, 1855) & 124.15 & 3.71 & 1.05 & 67.86 \\
Parapseudes latifrons (Grube, 1864) & 156.06 & 575.52 & 1.45 & 69.20 \\
Gammaropsis palmata (Stebbing y Robertson, 1891) & 12.66 & 44.56 & 1.83 & 70.47 \\
Astacillas sp. & 0.00 & 43.02 & 1.21 & 71.70 \\
Zeuzo normani (Richardson, 1905) & 344.20 & 193.85 & 1.73 & 72.93 \\
Ampithoe ramondi Audouin, 1826* & 4.91 & 108.44 & 3.10 & 74.15 \\
\hline * Species which are likely to be good discriminators of groups & & &
\end{tabular}

(18.4 $\mathrm{g} \mathrm{m}^{-2} \mathrm{mo}^{-1}$ ) and the highest average annual values $\left(29.78 \mathrm{~g} \mathrm{~m}^{-2} \mathrm{mo}^{-1}\right)$.

Organic matter in the silt (SOM) seemed to act inversely to siltation as the lowest annual average value occurred at the eastern side of the bay (SG, PA and TE, 8.8-10\%). In fact, there was a negative linear relationship between siltation and SOM $(r=-0.75, P<$ $0.001)$ which indicates that when siltation is lower, the sediment is richer in organic matter and viceversa.

The mean annual suspended solids were very similar at the various stations, with the highest mean value $\left(15.6 \mathrm{mg} \mathrm{L}^{-1}\right)$ at $\mathrm{PA}$ and SG. The maximum annual values $\left(38.5 \mathrm{mg} \mathrm{L}^{-1}\right)$ were registered at PA and the minimum (2.8 $\mathrm{mg} \mathrm{L}^{-1}$ ) at PG. Suspended solids and suspended organic matter followed the double reciprocal model $(\mathrm{y}=1 /(a+b / x), r=0.7, P<0.001)$, indicating a non-linear response between these parameters.

Water temperature ranged at $\mathrm{SG}$, from 14 to $23^{\circ} \mathrm{C}$, at $\mathrm{PA}$, from 14 to $22^{\circ} \mathrm{C}$, at $\mathrm{TE}$, from 17 a lo largo del mes, no pudiendo determinar qué tan representativa fue esta lectura.

El hidrodinamismo está relacionado inversamente con la localización espacial, de forma que las estaciones internas de la bahía se comportan de forma distinta a la externas. El valor medio más alto de hidrodinamismo se registró en SG $(6.14 \mathrm{~V})$, donde también se alcanzó el valor máximo anual (11.15 V).

La sedimentación tendió a ser mayor en la parte este de la bahía, aunque los valores máximos registrados en SG y en PA (10.2 y $10.38 \mathrm{~g}$ $\mathrm{m}^{-2} \mathrm{mes}^{-1}$, respectivamente) fueron menores que los obtenidos en CE (18.4 $\left.\mathrm{g} \mathrm{m}^{-2} \mathrm{mes}^{-1}\right)$. La estación TE presentó el máximo valor anual (18.4 $\mathrm{g} \mathrm{m}^{-2} \mathrm{mes}^{-1}$ ) y el valor medio anual más alto $\left(29.78 \mathrm{~g} \mathrm{~m}^{-2} \mathrm{mes}^{-1}\right)$. La materia orgánica del sedimento (SOM) parece comportarse de manera inversa a la sedimentación, ya que los valores anuales más bajos se registraron en la parte este de la bahía (SG, PA y TE, 8.8-10\%). De hecho, existe una relación lineal inversa entre la sedimentación y la SOM $(r=-0.75$, 
Hydrodynamism (V)

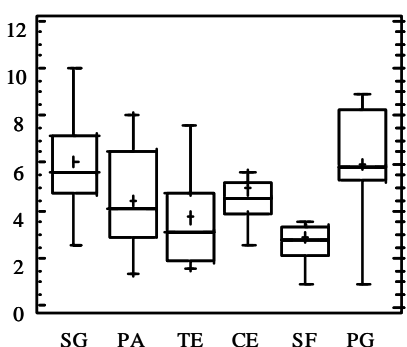

$\operatorname{SOM}(\%)$

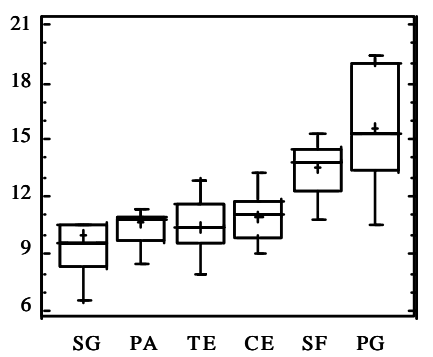

Silting $\left(\mathrm{g} / \mathrm{m}^{2} / \mathrm{month}\right)$

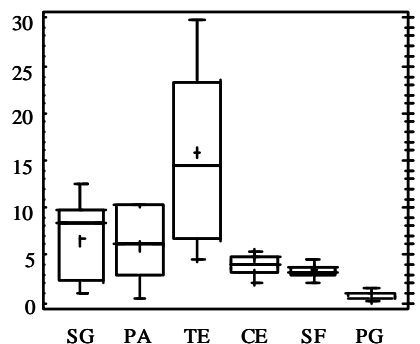

Suspended solids $(\mathrm{mg} / \mathrm{l})$

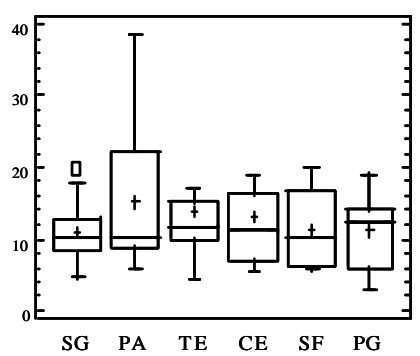

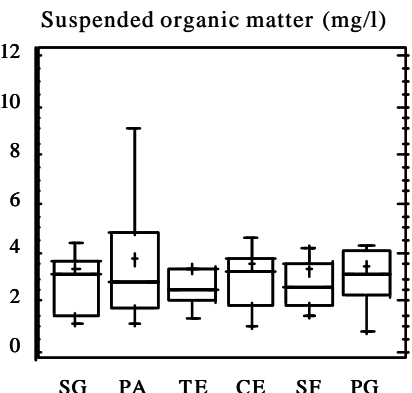

Figure 3. Multiple "box-and-whisker" plots for each abiotic variable at sampling stations. Stations code as in figure 1.

Figura 3. Gráficas "box-and-whisker" para cada una de las variables abióticas muestreadas en las estaciones. Código de las estaciones como en la figura 1.

to $24^{\circ} \mathrm{C}$, at $\mathrm{CE}$, from 15.5 to $26^{\circ} \mathrm{C}$, at $\mathrm{SF}$, from 16 to $24^{\circ} \mathrm{C}$ and, at $\mathrm{PG}$, from 16 to $24^{\circ} \mathrm{C}$.

The only abiotic variable (average annual values) that showed significant correlation to beta diversity was hydrodynamism, with a significant linear correlation between these two variables $(r=0.811, P<0.05)$.
$P<0.001)$ que indica que cuando la sedimentación es baja, el sedimento es rico en materia orgánica y viceversa. El valor anual de sólidos en suspensión fue muy similar en todas las estaciones estudiadas, con el valor promedio anual más alto $\left(15.6 \mathrm{mg} \mathrm{L}^{-1}\right)$ en PA y SG. El valor anual más alto fue el registrado en 
Ciencias Marinas, Vol. 27, No. 4, 2001

\section{Relationship between species and environmental variables}

Figure 4 shows the spatial ordination of sites based on species abundance with successively superimposed symbols, representing the respective values (annual averages) for the set of abiotic variables. In these plots, the ordination of stations is basically a function of the variability associated to the horizontal axis and can be explained only on the basis of a hypothetical hydrological gradient. Thus, the sites most exposed to currents are clustered at the left side and those in relatively calm conditions are at the right side. No other environmental factor did explain the distributional patterns of the peracarids.

The BIO-ENV procedure ascertained most accurately the relationship between the spatial distribution of the peracaridean and the environmental factors. The environmental variables that yielded the largest rank correlation, $\rho_{s}$ (Spearman coefficient), between abiotic and biotic similarities of the samples, and that best grouped consistently the sites with the peracaridean composition, were hydrodynamism $\left(\rho_{s}=0.58\right)$ followed by siltation $\left(\rho_{s}=0.25\right)$ (table 2). The best combination of variables involved hydrodynamism and siltation $\left(\rho_{s}=0.665\right)$. However, if dissolved organic matter or organic matter in the silt were included, the coefficient decreased to 0.47 or 0.32 , respectively, due to their negligible effect on the community structure (Clarke and Ainsworth, 1993).

To determine the influence of the independent abiotic variables on the abundance of the most relevant species, we carried out various multiple regression models. Only those species that had a significant relationship with these abiotic variables are shown in table 3. Two variables, hydrodynamism and siltation, explained over $40 \%$ of the variability in the distribution of Cressa mediterranea and Stenothoe
PA (38.5 mg L $\left.{ }^{-1}\right)$ y, el mínimo, el registrado en PG (2.8 mg L $\left.{ }^{-1}\right)$. Los sólidos en suspensión y la materia orgánica de éstos siguieron un modelo de doble recíproco $(\mathrm{y}=1 /(a+b / x), r=0.7$, $P<0.001)$, indicando una respuesta no lineal entre estas variables.

La temperatura varió en un rango de 14 a $23^{\circ} \mathrm{C}$ en $\mathrm{SG}$, de 14 a $22^{\circ} \mathrm{C}$ en $\mathrm{PA}$, de 17 a $24^{\circ} \mathrm{C}$ en TE, de 15.5 a $26^{\circ} \mathrm{C}$ en $\mathrm{CE}$, de 16 a $24^{\circ} \mathrm{C}$ en SF y de 16 a $24^{\circ} \mathrm{C}$ en PG.

La única variable abiótica (valores medios anuales) que presentó una corelacción significativa con la diversidad beta fué el hidrodinamismo, con una relación lineal entre estas dos variables $(r=0.811, P<0.05)$.

\section{Relaciones entre las especies y las variables medioambientales}

La figura 4 muestra la ordenación espacial de las estaciones según la abundancia de las especies mediante símbolos superpuestos de forma sucesiva, que representan los valores (promedios anuales) para cada una de las variables abióticas estudiadas. En estas gráficas, la ordenación de las estaciones está básicamente en función de la variabilidad asociada al eje horizontal y que puede ser explicada únicamente por un gradiente hipotético en el hidrodinamismo. De esta forma, las estaciones más expuestas a las corrientes se encuentran localizadas en el lado izquierdo de la gráfica y aquellas estaciones quietas o calmas, a la derecha. Ninguna otra variable abiótica explicó los patrones de distribución de los peracáridos.

El test BIO-ENV determinó, de una forma más precisa, las relaciones entre la distribución espacial de los peracáridos y las variables medioambientales. Las variables que en sí tuvieron una mayor correlacion $\rho_{s}$ (coeficiente de Spearman) entre las similitudes de los parámetros bióticos y abióticos, y que explicaron mejor la composición de los peracáridos fueron, el hidrodinamismo $\left(\rho_{s}=0.58\right)$ seguido 
Conradi et al.: Environmental variables and peracarid fauna in Algeciras Bay
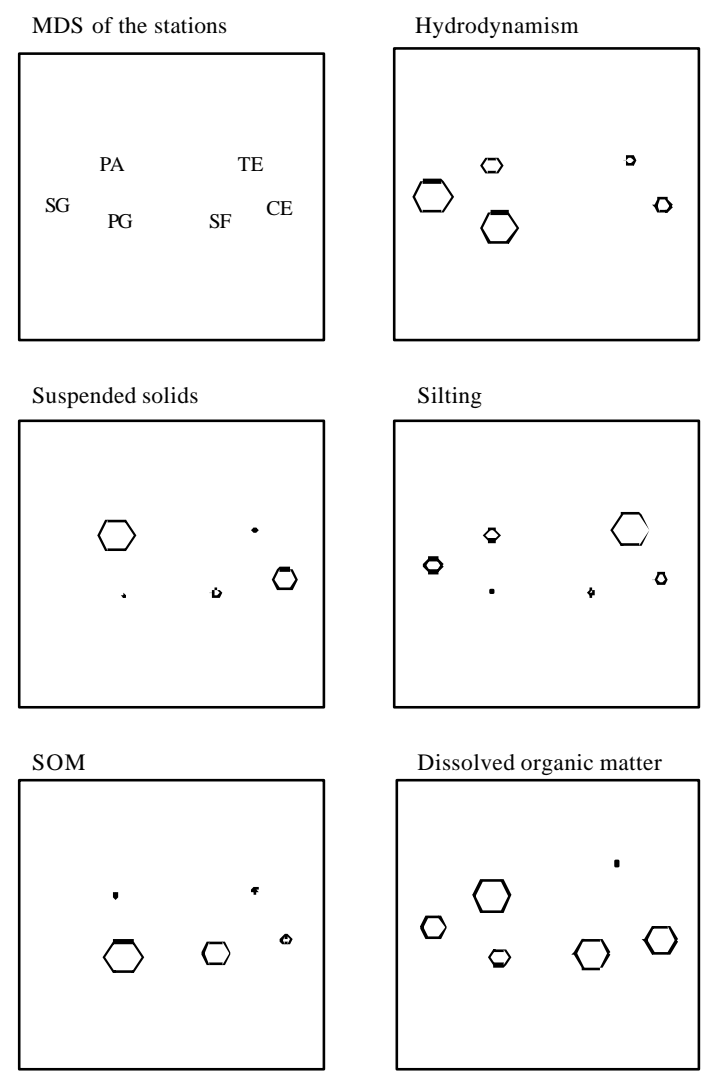

Figure 4. Two-dimensional MDS ordination of sites (as in fig. 3) but with hexagons of increasing size with increasing environmental factors superimposed (stress $=0.009$ ). Stations codes as in figure 1 .

Figura 4. Ordenación MDS de dos dimensiones de las estaciones (como en la fig. 3) pero con hexágonos superpuestos con tamaño creciente a medida que crece el valor de la variable medioambiental (estrés = 0.009). Código de las estaciones como en figura 1.

dollfusi. Three species, Ischyrocerus inexpectatus, Jassa marmorata and Podocerus variegatus were negatively correlated to hydrodynamism and positively correlated with siltation. Siltation explained over $2 \%$ of the variability of the distribution of Stenothoe tergestina and Lembos websteri. The first species had a positive correlation with siltation while this was negative for the last one. The abundance of Phtisica marina was negatively related to hydrodynamism. Some other species such as Aora spinicornis, Cumella limicola, de la sedimentación $\quad\left(\rho_{s}=0.25\right) \quad($ tabla 2$)$. La mejor combinación de las variables incluyó al hidrodinamismo y la sedimentación $\left(\rho_{s}=0.665\right)$. Sin embargo, si se consideraba la materia orgánica disuelta o la materia orgánica en el sedimento recolectado, este coeficiente decrecía hasta 0.47 o 0.32 , respectivamente, dado el escaso efecto combinado de estas variables sobre la estructura de la comunidad (Clarke y Ainsworth, 1993).

Para determinar la influencia de las variables abióticas independientes sobre la 
Table 2. Results of BIO-ENV analysis: Combinations of environmental variables, taken $k$ at a time, yielding the "best matches" of biotic and abiotic similarity matrices for each $k$, as measured by standard Spearman rank coefficients $\left(\rho_{s}\right)$. Bold type indicates the combination with maximum overall. Environmental factors are: hydrodynamism (Hyd), percentage of suspended organic matter (SusOM), organic matter in the silt (SOM), suspended solids (Sus) and silting (Silt).

Tabla 2. Resultados del análisis BIO-ENV: Combinaciones de variables medioambientales, tomadas cada $k$, dando el "mejor ajuste" de las matrices de similitud biótica y abiótica para cada $k$, por los coeficientes de Spearman $\left(\rho_{s}\right)$. Las negritas indican el máximo global. Los factores ambientales considerados son: hidrodinamismo (Hyd), porcentaje de materia orgánica en suspensión (SusOM), materia orgánica en sedimentos (SOM), sólidos en suspensión (Sus) y sedimentación (Silt).

Spearman rank correlation

\begin{tabular}{|c|c|c|c|c|c|}
\hline$k$ & & Best varia & ombinations & & \\
\hline 1 & $\begin{array}{l}\text { Hyd } \\
(0.58)\end{array}$ & $\begin{array}{l}\text { Silt } \\
(0.25)\end{array}$ & $\begin{array}{l}\text { SusOM } \\
(0.22)\end{array}$ & $\begin{array}{l}\text { SOM } \\
(0.12)\end{array}$ & $\begin{array}{l}\text { Sus } \\
(0.09)\end{array}$ \\
\hline 2 & $\begin{array}{l}\text { Hyd, Silt } \\
(0.66)\end{array}$ & $\begin{array}{l}\text { Hyd, SusOM } \\
(0.38)\end{array}$ & $\begin{array}{l}\text { Hyd, SOM } \\
(0.16)\end{array}$ & $\ldots$ & \\
\hline 3 & $\begin{array}{l}\text { Hyd, Silt, SusOM } \\
(0.47)\end{array}$ & $\begin{array}{l}\text { Hyd, Silt, SOM } \\
(0.32)\end{array}$ & $\ldots$ & & \\
\hline
\end{tabular}

Table 3. Multiple regression models between the abundance of some peracaridean species and the abiotic variables studied. Hydro $=$ hydrodynamism, Temp $=$ temperature and Silt $=$ siltation .

Tabla 3. Modelos de regresión múltiple entre la abundancia de algunas especies de peracáridos y las variables abióticas estudiadas. Hydro = hidrodinamismo, Temp = temperatura y Silt = sedimentación.

\begin{tabular}{llcc}
\hline Species & MODEL (Abundance $=\mathrm{a}+\mathrm{bx}+\mathrm{cz}+\ldots)$ & $r^{2}$ & $P$ \\
\hline Cressa mediterranea & $\mathrm{A}=2.076+0.911$ Hydro-0.764 Silt & 0.413 & 0.0019 \\
Ischyrocerus inexpectatus & $\mathrm{A}=-4.003-0.704$ Hydro+0.855 Temp & 0.335 & 0.0065 \\
Jassa marmorata & $\mathrm{A}=-5.791-1.592$ Hydro+1.183 Temp & 0.308 & 0.0096 \\
Podocerus variegatus & $\mathrm{A}=-1.348-0.853$ Hydro+0.598 Temp & 0.282 & 0.014 \\
Stenothoe dollfusi & $\mathrm{A}=4.557+0.662$ Hydro-0.723 Silt & 0.338 & 0.0061 \\
Stenothoe tergestina & $\mathrm{A}=1.121+0.769$ Silt & 0.186 & 0.0229 \\
Phtisica marina & $\mathrm{A}=13.277-0.601$ Hydro & 0.205 & 0.0299 \\
Lembos websteri & $\mathrm{A}=7.930-0.466$ Silt & 0.184 & 0.0235 \\
\hline
\end{tabular}


Conradi et al.: Environmental variables and peracarid fauna in Algeciras Bay

Lysianassa costae, Nanastacus unguiculatus, Paranthura nigropunctata, S. monoculoides and Tanais dulongii appeared sensitive to extreme siltation but they were not abundant enough to establish a relationship.

\section{DISCUSSION}

The many coastal anthropogenic impacts in Algeciras Bay (due mainly to industrial development) have created an uneven influence on hydrodynamic factors along its shoreline.

The importance of the hydrodynamism in the composition of the phytal or associated peracaridean fauna is well known (Dommasnes, 1968; Moore, 1973a, 1986; Scipione et al., 1981; Tararam and Wakabara, 1981; Procaccini and Scipione, 1992). In this study, hydrodynamism was the factor which had the most direct bearing on beta diversity and species distribution, either acting alone or in conjunction with other variables like siltation. Thus, it is not surprising that the abundances of some species such as Cressa mediterranea, Ischyrocerus inexpectatus, Jassa marmorata, Podocerus variegatus, Stenothoe dollfusi and Phtisica marina were negatively or positively related with hydrodynamism (table 3 ).

Hagerman (1966) observed a decrease in the diversity and an increase in the density of the amphipod faunas in environments with a high sedimentation rate. Both characteristics were found at the inner stations in Algeciras Bay, where species such as Caprella equilibra, Corophium acutum, Gammaropsis maculata, Ischyrocerus inexpectatus, Jassa marmorata, Parapseudes latifrons, Phtisica marina, Podocerus variegatus, Pseudoprotella phasma, Stenothoe tergestina were the most abundant (Conradi et al., 2000). However, only four species, Cressa mediterranea, Lembos websteri, Stenothoe dollfusi and S. tergestina were directly related to siltation. abundancia de las especies más relevantes, se llevaron a cabo varios modelos de regresión múltiple. En la tabla 3 se muestran sólo aquellas especies que mostraron una relación significativa con estas variables abióticas. La combinación de dos variables, el hidrodinamismo y la sedimentación, explicaron un $40 \%$ de la variabilidad en la distribución de Cressa mediterranea y Stenothoe dollfusi. Tres especies, Ischyrocerus inexpectatus, Jassa marmorata y Podocerus variegatus, se correlacionaron negativamente con el hidrodinamismo y positivamente con la sedimentación. Esta última variable explicó cerca del $2 \%$ de la variabilidad en la distribución de Stenothoe tergestina y Lembos websteri. La primera especie tuvo una relación positiva con la sedimentación, mientras que la segunda tuvo una correlación negativa con la misma variable. La abundancia de Phtisica marina estuvo correlacionada negativamente con el hidrodinamismo. Otras especies como Aora spinicornis, Cumella limicola, Lysianassa costae, Nanastacus unguiculatus Paranthura nigropunctata, Stenothoe monoculoides y Tanais dulongii son aparententemente sensibles a valores extremos de sedimentación pero no fueron suficientemente abundantes para establecer alguna relación.

\section{DISCUSIÓN}

Los impactos ambientales que han sufrido las costas de la Bahía de Algeciras (debido principalmente al desarrollo industrial) han creado una influencia desigual sobre el hidrodinamismo a lo largo de su línea de costa.

La importancia del hidrodinamismo en la composición de los anfípodos asociados a macrófitos es bien conocida (Dommasnes, 1968; Moore, 1973a, 1986; Scipione et al., 1981; Tararam y Wakabara, 1981; Procaccini y Scipione, 1992). En este estudio, el 
Trophic requirements and living habits will also affect the distribution and composition of the amphipod community (e.g., Desrosiers et al., 1986, 1990; Scipione, 1989; Nicotri, 1990; Procaccini and Scipione, 1992; Sánchez-Mata et al., 1993; Sparla et al., 1993; Conradi and Cervera, 1995; Conradi et al., 1997). Ampithoe ramondi, Apherusa bispinosa, Caprella acanthifera, Dexamine spinosa, Dexamine spiniventris, Elasmopus sp., Hyale perieri, and Pereionotopus testudo are herbivore species, although some of them can also feed on solid suspended matter (Biernaum, 1979; Reish and Barnard, 1979; Brawley and Adey, 1981; Procaccini and Scipione, 1992). In accordance with previous studies (Nicolaidou and Karakiri, 1989; Buschmann, 1990), these species were more abundant in environments with high algal biomass, as the external stations, (SánchezMoyano and García-Gómez, 1998) rather than at the inner stations, where high water turbidity avoids the development of most of the macrophyte species. On the other hand, filter-feeders such as Corophium acutum, Ischyrocerus inexpectatus, Jassa marmorata, and Podocerus variegatus were more abundant at the inner stations where siltation was higher.

Furthermore, the free-living fauna or species which directly attach to the substrate, such as Amphilochus picadurus, Apherusa bispinosa, Dexamine spinosa, D. spiniventris, Gitana sarsi, Hyale perieri, Peltocoxa gibbosa, P. marioni, Pereionotopus testudo and some caprellid species, were abundant in the environment with high hydrodynamism, as they are well adapted to it (Fenwick, 1976; Wakabara et al., 1983; Scipione, 1989). Tube-builder amphipods such as Corophium acutum, Gammaropsis maculata, Ischyrocerus inexpectatus and Jassa marmorata dominated in semi-enclosed or port environments. Thus, high siltation provides food and material to build their tubes and the low hydrodynamism hidrodinamismo, bien como variable única, o bien actuando conjuntamente con otras, como la sedimentación, fue el factor que estuvo más directamente relacionado con la diversidad beta y con la composición en las especies de peracáridos. De esta forma, no es sorprendente que algunas especies como Cressa mediterranea, Ischyrocerus inexpectatus, Jassa marmorata, Podocerus variegatus, Stenothoe dollfusi y Phtisica marina se encontraran negativa o positivamente relacionadas con el hidrodinamismo (tabla 3).

Hagerman (1966) observó un decremento en la diversidad y un aumento en la densidad de anfípodos en ambientes con tasas de sedimentación altas. Estas dos características se encontraron también en las estaciones más internas de la Bahía de Algeciras donde especies como Caprella equilibra, Corophium acutum, Gammaropsis maculata, Ischyrocerus inexpectatus, Jassa marmorata, Parapseudes latifrons, Phtisica marina, Podocerus variegatus, Pseudoprotella phasma y Stenothoe tergestina fueron las más abundantes (Conradi et al., 2000). Sin embargo, sólo cuatro especies, Cressa mediterranea, Lembos websteri, Stenothoe dollfusi y S. tergestina estuvieron directamente relacionadas con la sedimentación.

Los requerimientos tróficos así como los hábitos de comportamiento también afectan la distribución y composición de la comunidad de anfípodos (e.g., Desrosiers et al., 1986, 1990; Scipione, 1989; Nicotri, 1990; Procaccini y Scipione, 1992; Sánchez-Mata et al., 1993; Sparla et al., 1993; Conradi y Cervera, 1995; Conradi et al., 1997). Ampithoe ramondi, Apherusa bispinosa, Caprella acanthifera, Dexamine spinosa, Dexamine spiniventris, Elasmopus sp., Hyale perieri y Pereionotopus testudo son especies herbívoras, aunque 
Conradi et al.: Environmental variables and peracarid fauna in Algeciras Bay

do not disturb their constructions (Moore, 1973b; Taraman and Wakabara, 1981; Scipione, 1989; Procaccini and Scipione, 1992).

This study demonstrates that the physical variability in Algeciras Bay affects the abundance and species composition of bryozoanassociated peracarideans with different adaptive abilities and tolerances. Organisms can exist in a particular location only if their "ecological valency" (the group of biological conditions which allow a species to occur) is not in conflict with the environment. For this reason, animals and plants are living indicators of environmental characteristics. The usefulness of biological indicators or biotic indices has been demonstrated recently, although they cannot infer the type of stress to which the system is subject (Gray et al., 1990; Grall and Glémarec, 1997). In summary, we have placed some peracaridean species into different groups according to two aspects: their distribution and their relationship to environmental variables.

Group I: Species sensitive to anthropogenic stress. They present a great variability of food sources. In this group we include species such as those belonging to the genera Dexamine, Ampithoe, Apherusa or species such as Nannastacus unguiculatus, Cumella limicola, Lysianassa costae, Eusiroides dellavallei and Stenothoe monoculoides.

Group II: Species tolerant to strong hydrodynamism. These species may occur in unaltered conditions but intense water movement stimulates their populations. These are freeliving peracarideans, which often feed on suspended solids: Aora spinicornis, Microjassa cumbrensis, and Cressa mediterranea.

Group III: Species tolerant to high siltation and low hydrodynamism. These species are typical of port environments although they can appear in other types of habitats. They are mainly tube-builder and filter-feeding species: Jassa marmorata, Ischyrocerus inexpectatus, algunas de ellas pueden alimentarse también de la materia en suspensión (Biernaum, 1979; Reish y Barnard, 1979; Brawley y Adey, 1981; Procaccini y Scipione, 1992). Al igual que en otros trabajos (Nicolaidou y Karakiri, 1989; Buschmann, 1990), estas especies fueron más abundantes en hábitats con una alta biomasa algal, como ocurre en las estaciones externas, (Sánchez-Moyano y García-Gómez, 1998) ya que en las estaciones internas la alta turbidez del agua impedía el desarrollo de los macrófitos. Por el contrario, los filtradores como Corophium acutum, Ischyrocerus inexpectatus, Jassa marmorata y Podocerus variegatus fueron más abundantes en las estaciones internas donde se presentó mayor sedimentación.

Además, las especies libres o que viven directamente sujetas al sustrato, como Amphilochus picadurus, Apherusa bispinosa, Dexamine spinosa, D. spiniventris, Gitana sarsi, Hyale perieri, Peltocoxa gibbosa, $P$. marioni, Pereionotopus testudo y algunas especies de caprélidos, fueron más abundantes en ambientes con un fuerte hidrodinamismo, ya que están adaptadas a soportar corrientes fuertes (Fenwick, 1976; Wakabara et al., 1983; Scipione, 1989). Las especies tubícolas, como Corophium acutum, Gammaropsis maculata, Ischyrocerus inexpectatus y Jassa marmorata dominaron en ambientes semicerrados o en zonas portuarias. De esta forma, la sedimentación les proporciona alimento y material para construir sus tubos, y el bajo hidrodinamismo no destruye sus construcciones (Moore, 1973b; Taraman y Wakabara, 1981; Scipione, 1989; Procaccini y Scipione, 1992).

Este estudio demuestra que la variabilidad de las condiciones físicas en la Bahía de Algeciras afecta significativamente la abundancia y la composición de peracáridos asociados a briozoos que presentan diferentes habilidades adaptativas y tolerancias. Los 
Ciencias Marinas, Vol. 27, No. 4, 2001

Gammaropsis maculata, Corophium acutum, Stenothoe tergestina, and Podocerus variegatus.

\section{ACKNOWLEDGEMENTS}

Thanks to CEPSA, Sevillana de Electricidad, Excmo. Ayuntamiento de los Barrios and Mancomunidad de Municipios del Campo de Gibraltar for the financial support of this work.

\section{REFERENCES}

Biernaum, C.K. (1979). Influence of sedimentary factors on the distribution of benthic amphipods of Fishers Island sound, Connecticut. J. Exp. Mar. Biol. Ecol., 38: 201-223.

Brawley, S.H. and Adey, W.H. (1981). The effects of micrograzers on algal community structure in a coral reef microcosm. Mar. Biol., 61: 167-177.

Bray, R.J. and Curtis, J.L. (1957). An ordination of the upland forest communities of southern Wisconsin. Ecol. Monogr., 27: 325-349.

Buschmann, A.H. (1990). Intertidial macroalgae as refuge and food for amphipoda in Central Chile. Aquat. Bot. 36: 237-245.

Carrada, G.C. and Fresi, E. (1988). Le lagune salmastre costiere. Alcune riflesione sui problemi e sui metodi. In: G.C. Carrada, F. Cicogna \& E. Fresi (Eds), Le lagune costiere: ricerche e gestione. Centro Lubrense di Esplorazioni Marine (CLEM) Publ., Massalubrense: $39-51$.

Clarke K.R. (1993). Non-parametric multivariate analyses of changes in community structure. Austr. J.Ecol., 18: 117-143.

Clarke, K.R. and Ainsworth, M. (1993). A method of linking multivariate community structure to environmental variables. Mar. Ecol. Progr. Series, 92: 205-219.

Clarke, K.H. and Warwick, R.M. (1994). Changes in Marine Communities: An Approach to Statistical Analysis and Interpretation. Natural Environment Research Council, U.K. 144 pp. organismos pueden existir en un particular hábitat sólo si su "valencia ecológica" (grupo de condiciones biológicas que permiten la vida de esa especie) no está en conflicto con el medio ambiente. Por esta razón, los animales y las plantas pueden ser indicadores vivientes de las características medioambientales. La utilidad de los indicadores biológicos o índices bióticos ha sido demostrada recientemente (Gray et al., 1990; Grall y Glémarec, 1997) aunque éstos no necesariamente son indicativos del tipo de estrés al que el ecosistema se encuentra sometido. En resumen, en este trabajo se clasifican algunas especies de peracáridos de acuerdo a su distribución y su relación con las variables medioambientales.

Grupo I: Especies sensibles al estrés antropogénico. Estas especies tienen un amplio rango de fuentes alimenticias. En este grupo se incluyen especies pertenecientes a los géneros Dexamine, Ampithoe, Apherusa o algunas especies como Nannastacus unguiculatus, Cumella limicola, Lysianassa costae, Eusiroides dellavallei y Stenothoe monoculoides.

Grupo II: Especies tolerantes a altos valores de hidrodinamismo. Estas especies pueden aparecer en ecosistemas no alterados, pero un alto hidrodinamismo estimula el rápido desarrollo de sus poblaciones. Son especies libres que frecuentemente se alimentan de los sólidos en suspensión: Aora spinicornis, Microjassa cumbrensis y Cressa mediterranea.

Grupo III: Especies tolerantes a altas tasas de sedimentación y un bajo régimen hidrodinamico. Estas especies son típicas de ambientes portuarios, aunque también pueden aparecer en otros tipos de hábitats. Son fundamentalmente tubícolas y filtradores detritívoros: Jassa marmorata, Ischyrocerus inexpectatus, Gammaropsis maculata, Corophium acutum, Stenothoe tergestina y Podocerus variegatus. 
Conradi, M. and Cervera, J.L. (1995). Variability in trophic dominance of amphipods associated with the bryozoan Bugula neritina (L., 1758) in Algeciras Bay (Southern Iberian peninsula). Pol. Arch. Hydrobiol., 42(4): 483-494.

Conradi, M., López-González, P.J. and GarcíaGómez, J.C. (1997). The amphipod community as a bioindicator in Algeciras bay (Southern Iberian Peninsula) based on a spatio-temporal distribution. PSZN Mar. Ecol., 18(2). 97-111.

Conradi, M., López-González, P.J., Cervera, J.L. and García-Gómez, J.C. (2000). Seasonality and spatial distribution of peracarids associated with the bryozoan Bugula neritina (L.) in Algeciras Bay, Spain. J. Crust. Biol., 20(2): 334-349.

Desrosiers, G., Bellan-Santini, D. and Brethes, J.C. (1986). Organisation trophique de quatre peuplements de substrats rocheux selon un gradient de pollution industriell (Golfe de Fos, France). Mar. Biol., 91: 107-120.

Desrosiers, G., Bellan-Santini, D., Brethes, J.C. and Willsie, A. (1990). Variability in trophic dominance of crustaceans along a gradient of urban and industrial contamination. Mar. Biol., 105: 137-143.

Dommasnes, A. (1968). Variations in the meiofauna of Corallina officinalis L. with wave exposure. Sarsia, 34: 117-124.

Fenwick, G.D. (1976). The effect of wave exposure on the amphipod fauna of the alga Caulerpa brownii. J. Exp. Mar. Biol. Ecol., 25: 1-18.

Gambi, M.C., Buia, M.C., Casola, E. and Scardi, M. (1989). Estimates of water movement in Posidonia oceanica beds: a first approach.International Workshop on Posidonia beds 2, 101-12.

Grall, J. and Glémarec, M. (1997). Using biotic indices to estimate macrobenthic community perturbations in the Bay of Brest. Est. Coast. Shelf Sci., 44A: 43-53.

Gray, J.S., Clarke, K.R., Warwick, R.M. and Hobbs, G. (1990). Detection of initial effects of pollution on marine benthos: an example from the Ekofisk and Eldfisk oilfields, North Sea. Mar. Ecol. Progr. Ser., 66: 285-299. Hagerman, L. (1966). The macro- and microfauna associated with Fucus serratus L. With some ecological remarks. Ophelia, 3: 1-43.

\section{AGRADECIMIENTOS}

Gracias a CEPSA, a Sevillana de Electricidad, al Excmo. Ayuntamiento de los Barrios y a la Mancomunidad de Municipios del Campo de Gibraltar por la financiación de este trabajo.

Traducido al español por los autores.

Moore, P. G. (1972). Particulate matter in the sublittoral zone of an exposed coast and its ecological significance with special references to the fauna inhabiting kelpholdfast. J. Exp. Mar. Biol. Ecol., 10: 59-80.

Moore, P.G. (1973a). The kelp fauna of north-east Britain. I. Introduction and the physical environment. J. Exp. Mar. Biol. Ecol., 13: 97125.

Moore, P.G. (1973b). The larger crustacea associated with holdfast of kelp (Laminaria hyperborea) in north-east Britain. Cah. Biol. Mar., 14: 493-518.

Moore, P.G. (1986). Seaweed-associated animal communities in the Firth of Clyde, with special reference to the population biology on the amphipod Hyale nilssoni (Rathke). Procc. R Soc. Edinburg, 90B: 271-286.

Nicolaidou, A. and Karakiri. M. (1989). The distribution of amphipoda in a brackish-water lagoon in Grecee. PSZN: Mar. Ecol., 10(2): 131139.

Nicotri, M.E. (1990). Factors involved in herbivore food preference. J. Exp Mar. Biol. Ecol., 42: 1326.

Pearson, T.H., and Rosenberg, R. (1978) Macrobenthic succession in relation to organic enrichment and pollution of the marine environment. Oceanogr. Mar. Biol., 16: 229311.

Procaccini, G. and Scipione, M.B. (1992). Observations on the spatio-temporal distribution of crustacean amphipods in the Fusaro coastal Lagoon (Central Tyrrhenian sea, Italy) and some notes on their presence in Mediterranean lagoons. PSZNapoli: Mar. Ecol., 13 (3): 203224. 
Ciencias Marinas, Vol. 27, No. 4, 2001

Reish, D.J. and Barnard, J.L. (1979). Amphipods (Arthopoda: Crustacea: Amphipoda). In: S. Fuller and D.R. Hart (eds). Academic Press, London and New York, 345-366.

Sánchez-Mata, A., Lastra, M. and Mora, J. (1993). Macrobenthic crustacean characterizacion of an estuarine area. Crustaceana, 64 (3): 337-355.

Sánchez-Moyano, J.E. and García-Gómez, J.C. (1998). The arthropod community, especially crustacea, as a bioindicator in Algeciras Bay (Southern Spain) based on a spatial distribution. J. Coast. Research, 14 (3): 1119-1133.

Scipione, M.B. (1989). Comportamento trofico dei Crostacei Anfipodi in alcuni sistemi bentonici costieri. Oebalia, 15 (1): 249-260.

Scipione, M.B., Carnevale, G., Finelli, F., Fresi, E., Mazzella, L., Ponticelli, M.P. and Taramelli, E. (1981). Ricerche sui popolamenti bentonici di substrato duro del porto dÍschia. infralitorale fotofilo III. Anfipodi. Quaderno di Laboro e Tecniches di Pesca 3 (1): 505-517.

Sneath, P.H.A. and Sokal, R.R. (1973). Numerical Taxonomy. The principles and practice of numerical classification. WH Freeman and Company, San Francisco. 573 pp.

Sparla, M.P., Scipione, M.B. and S. Riggio. (1993). Peracarid crustacea inhabiting aegagropylae of the red alga Rytiphloea tinctoria (Clemente) C.AG. in the Stagnone sound, Western Sicily, Italy. Crustaceana 64 (1): 1-17.

Strickland, J.D.H. and Parson, T.R. (1969). A practical handbook of sea water analysis. Fish. Resear. Board Can. Bull., 167.

Taraman, A.S. and Wakabara, Y. (1981). The mobile fauna -specially Gammaridea- of Sargassum cymosum. Mar. Ecol. Progr. Ser., 5: 157-163.

Wakabara, Y., Tararam, A.S. and Takeda, A.M. (1983). Comparative study of the amphipoda fauna living on Sargassum of two Itanhaém shores, Brazil. J. Crust. Biol., 3 (4): 602-607.

Warwick, R.M. and Clarke, K.R. (1993). Comparing the severity of disturbance: a meta-analysis of marine macrobenthic community data. Mar. Ecol. Progr. Ser., 92: 221-231.

Wilson, M.V. and Shmida, A. (1984). Measuring beta diversity with presence-ausence data. J. Ecol., 72: 1055-1064. 